\title{
Paradoxical Actions of Hydrogen Peroxide on Long-Term Potentiation in Transgenic Superoxide Dismutase-1 Mice
}

\author{
Ariel Kamsler and Menahem Segal \\ Department of Neurobiology, The Weizmann Institute, Rehovot 76100, Israel
}

\begin{abstract}
Hydrogen peroxide $\left(\mathrm{H}_{2} \mathrm{O}_{2}\right)$, a reactive oxygen species, is assumed to have a detrimental effect on neuronal plasticity. Indeed, $\mathrm{H}_{2} \mathrm{O}_{2}$ suppresses long-term potentiation (LTP) in hippocampal slices of normal rats and wild-type (wt) mice. Transgenic mice overexpressing superoxide dismutase (SOD) 1 (tg-SOD), which maintain high ambient $\mathrm{H}_{2} \mathrm{O}_{2}$, have also been shown to be impaired in their ability to express hippocampal LTP. Paradoxically, $\mathrm{H}_{2} \mathrm{O}_{2}$, at a concentration $(50 \mu \mathrm{M})$ that blocks LTP in wt mice, actually enhanced LTP in slices of 2-month-old tg-SOD mice. $\mathrm{H}_{2} \mathrm{O}_{2}$-dependent LTP in tg-SOD was blocked by the protein phosphatase calcineurin inhibitor FK506, but not by rapamycin, an FK-binding protein 12 (FKBP12) inhibitor or by 1-(5-isoquinolinesulfonyl)-2-methylpiperazine (H7), a serine-kinase inhibitor. Interestingly, wt and tg-SOD mice expressed similar levels of the antioxidant enzyme catalase and similar activity of glutathione peroxidase. An opposite situation was found in 2-year-old mice. Aged wt mice were impaired in LTP in a manner that could be reversed by the addition of $\mathrm{H}_{2} \mathrm{O}_{2}$. Surprisingly, aged tg-SOD mice exhibited larger LTP than that found in wt mice, but this was now reduced by 50 $\mu \mathrm{M} \mathrm{H}_{2} \mathrm{O}_{2}$. Both young tg-SOD and aged control mice displayed altered protein phosphatase activity, compared with that of young controls; moreover, FK506 inhibited LTP in old tg-SOD as well as in old wt mice treated with $\mathrm{H}_{2} \mathrm{O}_{2}$. These data promoted a dual role for $\mathrm{H}_{2} \mathrm{O}_{2}$ in the regulation of LTP, and proposed that it is mediated by the protein phosphatase calcineurin.
\end{abstract}

Key words: CA1, hippocampus; LTP; long-term potentiation; oxidation; phosphatase; slice

\section{Introduction}

Metabolic products of oxidation/reduction processes such as hydrogen peroxide $\left(\mathrm{H}_{2} \mathrm{O}_{2}\right)$ have been considered, until recently, only in the context of the homeostatic maintenance of cellular functions. Thus, a decline in the regulation of reactive oxygen species (ROS) at older ages (Beckman and Ames, 1998) has been assumed to underlie the emergence of neurodegenerative processes associated with aging. However, a growing body of evidence implicates $\mathrm{H}_{2} \mathrm{O}_{2}$ in neuronally significant signaling processes (Klann and Thiels, 1999; Kamsler and Segal, 2003). Under normal conditions, superoxide radicals produced by the mitochondria but also by the activity of ion channels are scavenged by the enzyme $\mathrm{Cu} / \mathrm{Zn}$ superoxide dismutase (SOD). SOD converts superoxides to $\mathrm{H}_{2} \mathrm{O}_{2}$, which is a less reactive, membranepermeable intermediate that is normally converted to $\mathrm{H}_{2} \mathrm{O}$ and $\mathrm{O}_{2}$ by myriad cellular antioxidants, including catalase and glutathione peroxidase (Gpx). Interestingly, the gene encoding the SOD mRNA resides in humans on chromosome 21 in a region that is triplicated in Down's syndrome and as such, has been implicated in the neuropathology of this and other neurodegenerative syndromes.

Transgenic mice overexpressing human $\mathrm{Cu} / \mathrm{Zn}$ SOD (tgSOD) have been generated (Epstein et al., 1987) and studied as a

\footnotetext{
Received July 3, 2003; revised Sept. 22, 2003; accepted Sept. 24, 2003.

This work was supported by Grant IIRG-00-2152 from the Alzheimer's Association. We thank M. Brodt for comments on previous versions of this manuscript.

Correspondence should be addressed to Dr. Menahem Segal, Department of Neurobiology, The Weizmann Institute, Rehovot 76100, Israel. E-mail: menahem.segal@weizmann.ac.il.

Copyright $\odot 2003$ Society for Neuroscience 0270-6474/03/2310359-09\$15.00/0
}

tentative model of oxidative stress leading to neurodegeneration. The transgenic strains that we are currently using express a sixfold increase in activity of the enzyme in the brain. Thymocytes from tg-SOD mice have been shown to produce more $\mathrm{H}_{2} \mathrm{O}_{2}$ than controls (Peled-Kamar et al., 1995). The neuromuscular junction in the tongue of tg-SOD mice is impaired (Yarom et al., 1988), and they also exhibit thymic abnormalities (Peled-Kamar et al., 1995). On the other hand, tg-SOD mice were found to be more resistant than their wild-type (wt) counterparts to focal cerebral ischemic injury (Kinouchi et al., 1991, Saito et al., 2003). Although kainate-induced cell death is exacerbated in cultured neurons from tg-SOD mice, animals injected with kainate are protected from seizure compared with controls (Levkovitz et al., 1999), which may be because of a higher activity of inhibitory interneurons. Tg-SOD mice were also impaired in hippocampal long-term potentiation (LTP), both in vivo and in vitro (Gahtan et al., 1998, Levkovitz et al., 1999).

We have shown recently (Kamsler and Segal, 2003) that exposure of a hippocampal slice to a low concentration of $\mathrm{H}_{2} \mathrm{O}_{2}$ can alter LTP induced by $100 \mathrm{~Hz}$ tetanus as well as long-term depression in rat hippocampal slices without affecting baseline EPSP attributes in a manner that is reversible by blockers of protein phosphatase. In that study, we demonstrated that a potentiating action of $\mathrm{H}_{2} \mathrm{O}_{2}$ on LTP could be mimicked by the application of a more vigorous stimulation protocol. We now use hippocampal slices from tg-SOD mice and evoked LTP by theta burst stimulation (TBS), which is patterned after innate rhythms in the hippocampus and is a milder stimulation that does not saturate the LTP generating mechanism (Morgan and Teyler, 2001), to fur- 
ther investigate the role of $\mathrm{H}_{2} \mathrm{O}_{2}$ as a diffuse modulator of synaptic plasticity.

\section{Materials and Methods}

All chemicals used, including $\mathrm{H}_{2} \mathrm{O}_{2}$, xanthine, xanthine oxidase enzyme, $\mathrm{N}$-T-butyl-phenylnitrone (BPN), 1-(5-isoquinolinesulfonyl)-2-methylpiperazine (H7), as well as antibodies were purchased from Sigma (St. Louis, MO). FR900506 (FK506) was a gift from Fujisawa Pharmaceuticals (Osaka, Japan). Rapamycin was purchased from Alomone Labs (Jerusalem, Israel). The fluorescent dye 2,7-dichlorofluorescein (DCF) was purchased from Molecular Probes (Eugene, OR).

Transgenic mice. Homozygous tg-SOD (tg-SOD51) animals overexpress the entire native human $\mathrm{Cu} / \mathrm{Zn}$ SOD gene with its own promoter (Epstein et al., 1987). Tg-SOD mice were developed from outbred mating $\left(\mathrm{F}_{1}\right)$ between $\mathrm{CBYB} / 6\left[(\mathrm{BALB} / \mathrm{c} \times \mathrm{C} 57 \mathrm{BL} / 6 \mathrm{~J}) \mathrm{F}_{1}\right]$ and $\mathrm{B} 6 \mathrm{D} / 2[(\mathrm{C} 57 \mathrm{BL} /$ $\left.6 \mathrm{~J} \times \mathrm{DBA}) \mathrm{F}_{1}\right]$. Mice with the same background but lacking the transgene were inbred for use as wt. The enzymatic activity of the transgene in these mice represents a sixfold increase over the level of endogenous $\mathrm{Cu} / \mathrm{Zn}$ SOD in the brain of control mice. During the establishment of the colony, the presence of the transgene was followed by SOD gel activity (showing mouse and human proteins in brain extracts) as well as PCR from tail genomic DNA. The homozygosity for $S O D$ genes was predicted by quantitative PCR and confirmed by backcrossing tg-mice with control animals. No noticeable phenotype was observed concerning young or adult mice, except that tg-SOD animals are somewhat smaller than controls.

Electrophysiology. The methods for preparation and recording from the slices have been detailed previously (Kamsler and Segal, 2003). Briefly, hippocampal slices were prepared from 2-month-old or 2-yearold male tg-SOD or wt mice. After rapid decapitation, the brain was placed in ice-cold artificial CSF (ACSF) containing the following (in mM): $124 \mathrm{NaCl}, 2 \mathrm{KCl}, 26 \mathrm{NaHCO}_{3}, 1.24 \mathrm{KH}_{2} \mathrm{PO}_{4}, 2.5 \mathrm{CaCl}_{2}, 2 \mathrm{MgSO}_{4}$, and 10 glucose, $\mathrm{pH}$ 7.4. The hippocampi were removed, and $350 \mu \mathrm{m}$ slices were made with a McIlwain tissue slicer and incubated in ACSF for $1.5 \mathrm{hr}$ at room temperature. The ACSF was saturated with a $95 \% \mathrm{O}_{2}$ and $5 \% \mathrm{CO}_{2}$ gas mixture. After incubation, the slices were submerged in a perfusion chamber. Recordings were made with a glass pipette containing $0.75 \mathrm{M} \mathrm{NaCl}(4 \mathrm{M} \Omega)$ placed in the stratum radiatum of the CA1 region of the hippocampus. Stimulation was delivered through two sets of bipolar nichrome electrodes placed in the stratum radiatum on either side of the recording electrode such that two independent stimulation pathways were used for each slice (Fig. 1, inset). Test stimulation was set so that EPSPs were $50 \%$ of maximum. After stable baseline recordings for at least $10 \mathrm{~min}$, LTP was induced by TBS of the Schaffer collaterals (10 trains of 4 pulses at $100 \mathrm{~Hz}$ separated by $200 \mathrm{msec}$ intertrain intervals at the same intensity as the test stimulation). Stimulation and data acquisition were performed using the LTP Program (Anderson and Collingridge, 2001). Drugs were added into the perfusion medium with special care so as to prevent changes in temperature, $\mathrm{pH}$, flow rate, or degree of oxygenation of the ACSF.

Antioxidant measurements. Samples for the antioxidant activity assay were collected as follows: 2 -month-old tg-SOD and wt mice were anesthetized intraperitoneally with $85 \%$ ketamine and $15 \%$ xylazine. They were then perfused with PBS to remove all the blood from the brain. Next, the brain was removed and the hippocampi were dissected out, homogenized in $50 \mathrm{~mm}$ phosphate buffer, $\mathrm{pH} 7.2,0.1 \%$ Triton X-100, in the presence of a protease inhibitor mixture (Sigma), and centrifuged for $1 \mathrm{hr}$ at $60,000 \times g$, after which the supernatants were collected. Protein concentrations were determined by the Bradford method (Bio-Rad, Hercules, CA).

Glutathione peroxidase activity was determined spectrophotometrically using the method of Flohe and Gunzler (1984), following the disappearance of NADPH as it is consumed to reduce peroxidized glutathione by glutathione reductase in the presence of $t$-butyl-hydroperoxide. Briefly, five concentrations of each sample were incubated in phosphate buffer $(0.1 \mathrm{M}, \mathrm{pH} 7)$ containing $0.1 \mathrm{~m}$ EDTA. Next, $10 \mathrm{~mm}$ reduced glutathione was added, followed by $0.25 \mathrm{U}$ of glutathione reductase enzyme, and the reaction mixture was allowed to equilibrate for $5 \mathrm{~min}$. Next, $\mathrm{NADPH}(1.5 \mathrm{~mm})$ was added, and again the reaction mixture was allowed to equilibrate. Finally, $t$-butyl-hydroperoxide $(12 \mathrm{~mm})$ was added and the
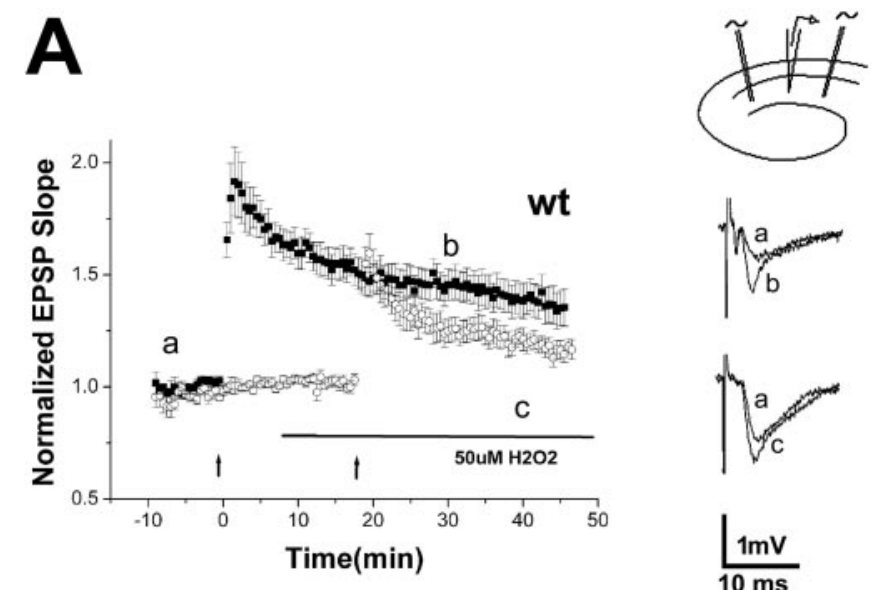

$1 \mathrm{mV}$ $10 \mathrm{~ms}$

B
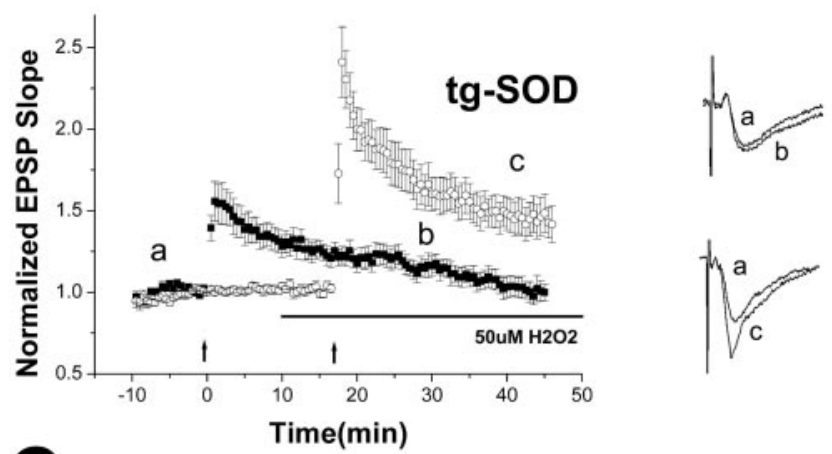

C

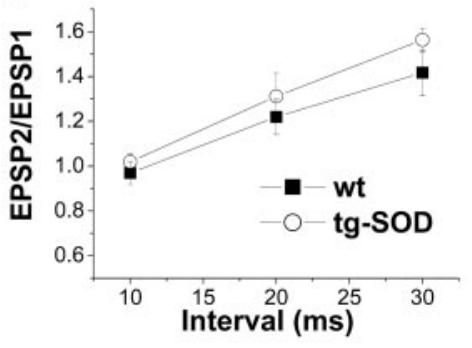

wt

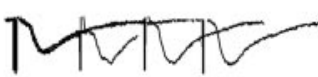

$\operatorname{tg}-S O D$

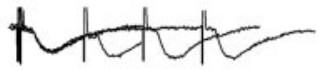

Figure 1. $\mathrm{H}_{2} \mathrm{O}_{2}$ reverses impaired LTP in $\mathrm{tg}$-SOD mice. The experimental preparation shown schematically in the inset (top right) included a recording electrode placed in the stratum radiatum and two stimulating electrodes placed on either side such that two independent stimulation pathways could be used. A, LTP in hippocampal slices from 2-month-old wt mice was induced by TBS in the first pathway (arrow). Before TBS in the second pathway, the slice was perfused with $50 \mu \mathrm{M} \mathrm{H}_{2} \mathrm{O}_{2}$, which inhibited LTP. $a-c$, Representative traces of EPSPs at indicated times. $B$, A similar experiment shows that $\mathrm{H}_{2} \mathrm{O}_{2}$ markedly enhances potentiation in slices taken from tg-SOD mice, which otherwise express a low level of LTP. C, Paired-pulse potentiation is not different between genotypes. The ratio of the second EPSP slope to the first is plotted as a function of the interval between them. Right, Representative traces of the data summarized on the left.

disappearance of NADPH was measured at $340 \mathrm{~nm}$. The enzymatic activity was calculated from the initial linear stage of the reaction.

For measurement of catalase immunoreactivity, equivalent amounts of protein were boiled for $5 \mathrm{~min}$ and separated on 12\% SDS-PAGE. They were then transferred to nitrocellulose membranes, blocked for $1 \mathrm{hr}$ in $1 \%$ skim milk in Tris-buffered saline with $0.05 \%$ Tween 20 . The blots were incubated overnight with anticatalase monoclonal antibodies (Sigma). The blots were washed with T-Tris-buffered saline and incubated with horseradish peroxidase-conjugated secondary antibodies for $1 \mathrm{hr}$. Protein signals were visualized with enhanced chemiluminescence. The 
blots were then stripped with $0.5 \%$ SDS and stained again with antibodies raised against neuron-specific enolase as a loading control. Quantification was performed using Scion Image (Frederick, MD) software.

Phosphatase activity assay. Hippocampal slices (seven to eight for each treatment) were placed in the perfusion chamber and exposed to either ACSF or to ACSF containing $50 \mu \mathrm{M} \mathrm{H}_{2} \mathrm{O}_{2}$. The slices were collected, washed with cold saline, and homogenized in lysis buffer supplied with the calcineurin assay kit (Biomol Research Laboratories, Hamburg, Germany), containing $50 \mathrm{~mm}$ Tris, $\mathrm{pH}$ 7.5, $0.1 \mathrm{~mm}$ EDTA, 0.1 mM EGTA, 1 тм DTT, and $0.2 \% \mathrm{NP}-40$. The samples were centrifuged at $100,000 \times g$ for $45 \mathrm{~min}$, and the supernatant was filtered through a desalting column for the removal of free phosphates. The filtered samples were incubated at $30^{\circ} \mathrm{C}$ for $15 \mathrm{~min}$ in reaction buffer from the kit without okadaic acid for the purpose of measuring total serine threonine phosphatase activity. The enzyme activity was expressed in nanomoles of Pi released from the substrate per milligram of protein. The serine/threonine phosphatase substrate sequence is Asp-Leu-Asp-Val-Pro-Ile-Pro-Gly-Arg-Phe-AspArg-Arg-Val-pSer-Val-Ala-Ala-Glu. The sequence is from PKA regulatory subunit type II.

ROS measurements. Endogenous hydrogen peroxide levels were determined using a variation of the method described by Cathcart et al. (1983). Briefly, hippocampal slices from 2-month-old and 2-year-old wt and tg-SOD mice were incubated in HEPES-buffered medium. Next, 2,7-DCF was freshly prepared at a final concentration of $2-5 \mu \mathrm{M}$ and added to a slice. The presence of $\mathrm{H}_{2} \mathrm{O}_{2}$ was measured as the average fluorescence measured across the slice at $488 \mathrm{~nm}$ using a Sensicam cCCD camera (PCO, Kelheim, Germany) and analyzed by Axon Imaging Workbench software (Axon Instruments, Foster City, CA).

Statistical analysis was done by using one-way ANOVA followed by Tukey's multiple comparison test, or Student's $t$ test whenever applicable.

\section{Results}

$\mathrm{H}_{2} \mathrm{O}_{2}$ rescues LTP in tg-SOD slices

We have shown recently (Kamsler and Segal, 2003) that $20 \mu \mathrm{M}$ $\mathrm{H}_{2} \mathrm{O}_{2}$ can inhibit LTP induction in rats without affecting baseline response properties or pre-established LTP. We sought to test whether a similar effect could be found in mice hippocampal slices. A $20 \mu \mathrm{M}$ concentration of $\mathrm{H}_{2} \mathrm{O}_{2}$ did not change the response to TBS in slices taken from wt mice (data not shown). However, $50 \mu \mathrm{M} \mathrm{H}_{2} \mathrm{O}_{2}$ did produce effects in mouse slices similar to those seen in rat slices exposed to $20 \mathrm{MM} \mathrm{H}_{2} \mathrm{O}_{2}$ : The EPSP slope was $1.45 \pm 0.06$ of baseline $30 \mathrm{~min}$ after TBS in control conditions (Fig. $1 A$ ), whereas in the presence of $50 \mu \mathrm{M} \mathrm{H}_{2} \mathrm{O}_{2}$, EPSPs were $1.16 \pm 0.04$ of baseline $(n=12 ; F=16.2 ; p<0.05)$. The higher $\mathrm{H}_{2} \mathrm{O}_{2}$ concentration required for mice over rats may be attributable in part to the higher metabolic rate of mice compared with rats (Davson, 1964).

Tg-SOD mice have been shown previously to be impaired in LTP (Gahtan et al., 1998, Thiels et al., 2000), despite a normal response to afferent stimulation (see below) and a normal shortterm plasticity evident from responses to paired-pulse stimulation (Fig. 1C). In the present experiments, tg-SOD slices were impaired in LTP induction, as we have found previously (Fig. $1 B)$; EPSPs were only $1.16 \pm 0.06$ of baseline $30 \mathrm{~min}$ after TBS $(n=12)$.

Our previous findings, that $1 \mu \mathrm{M} \mathrm{H}_{2} \mathrm{O}_{2}$ could cause a twofold enhancement of LTP in rat hippocampal slices (Kamsler and Segal, 2003), prompted us to investigate the effect of $\mathrm{H}_{2} \mathrm{O}_{2}$ on tg-SOD slices. Surprisingly, $50 \mu \mathrm{M} \mathrm{H}_{2} \mathrm{O}_{2}$ resulted in enhanced LTP in that EPSPs were $1.49 \pm 0.11$ of baseline, similar to those of untreated wt mice and significantly higher than untreated tgSOD slices $(F=34.9 ; p<0.05)$.
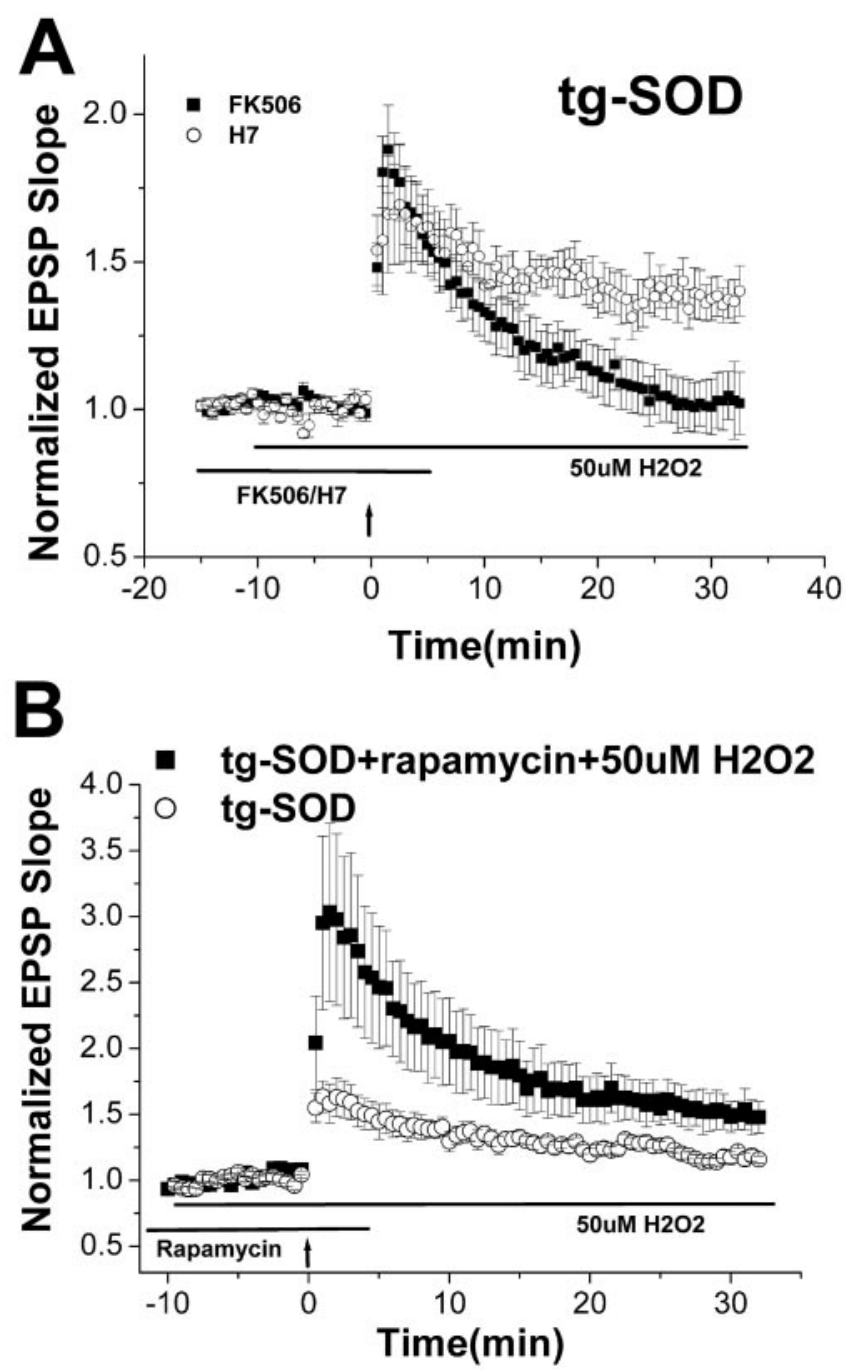

Figure 2. Calcineurin activity is required for $\mathrm{H}_{2} \mathrm{O}_{2}$-dependent LTP. A, EPSP slopes of 2-month-old tg-SOD mice treated with $50 \mu \mathrm{M} \mathrm{H}_{2} \mathrm{O}_{2}$ and $10 \mu \mathrm{m} \mathrm{H7}$ or $20 \mu \mathrm{m}$ FK506. Treatment with $\mathrm{H}_{2} \mathrm{O}_{2}$ restores $\mathrm{LTP}$ in response to TBS (Fig. 1), whereas adding FK506 (squares) but not $\mathrm{H} 7$ (circles) abolishes the effect of $\mathrm{H}_{2} \mathrm{O}_{2}$. B, Rapamycin does not mimic the effect of FK506 to inhibit $\mathrm{H}_{2} \mathrm{O}_{2}$-dependent LTP in tg-SOD slices. Adding rapamycin and $50 \mu \mathrm{M} \mathrm{H} \mathrm{H}_{2} \mathrm{O}_{2}$ results in LTP (squares), whereas untreated tg-SOD mice are impaired in LTP (circles) as in Figure $1 B$.

\section{Calcineurin mediates the $\mathrm{H}_{2} \mathrm{O}_{2}$-dependent LTP}

The protein phosphatase calcineurin has been shown to have high activity levels in both aged animals (Foster et al., 2001) and in slices exposed to $\mathrm{H}_{2} \mathrm{O}_{2}$ (Kamsler and Segal, 2003). Therefore, we examined the effect of the calcineurin inhibitor FK506 on the action of $\mathrm{H}_{2} \mathrm{O}_{2}$ (Fig. $2 \mathrm{~A}$ ). FK506 totally blocked the enhancing action of $\mathrm{H}_{2} \mathrm{O}_{2}$ on LTP in the tg-SOD slices; the EPSP slopes were $1.01 \pm 0.09$ of baseline some $30 \mathrm{~min}$ after TBS in the presence of FK506 $(n=11)$ similar to tg-SOD slices without $\mathrm{H}_{2} \mathrm{O}_{2}$. FK506 forms a complex with FK-binding protein 12 (FKBP12), which then blocks the activity of calcineurin. To confirm the specificity of the calcineurin antagonistic action of FK506, we added rapamycin, an FKBP12-binding drug that does not interact with calcineurin. In the presence of $\mathrm{H}_{2} \mathrm{O}_{2}$ and rapamycin, the EPSP slope was $1.49 \pm 0.11$ of baseline $(n=8) 30 \mathrm{~min}$ after TBS, as seen with tg-SOD slices exposed to $\mathrm{H}_{2} \mathrm{O}_{2}$ alone. This indicates that calcineurin activity and not FKBP12 activity is necessary for the $\mathrm{H}_{2} \mathrm{O}_{2}$-mediated rescue of LTP in tg-SOD mice.

We also examined the effect of protein kinases on the action of 


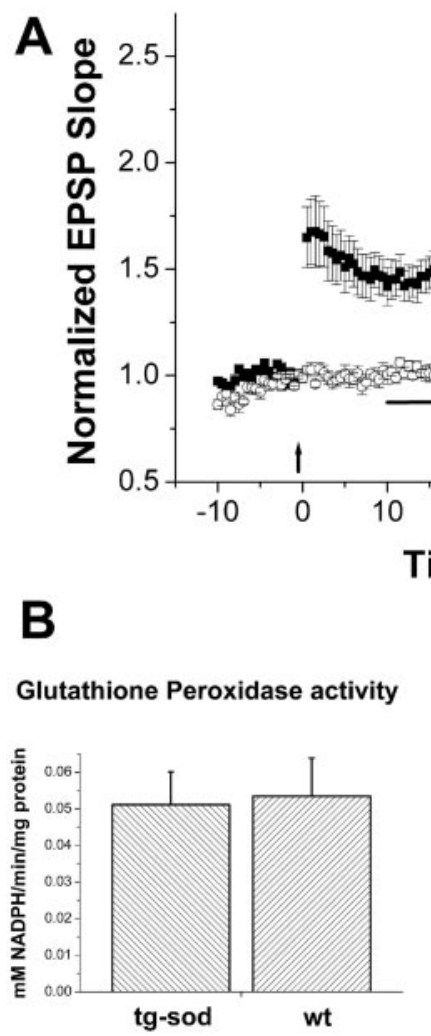

Figure 3. Tg-sod mice exhibit a complex redox environment. $A$, Tg-SOD mice ( 2 months old) were treated with BPN (bar), and TBS was applied to two pathways (arrows). BPN affected both the maintenance (squares) and the induction (circles) of LTP. B, Hippocampi from 2-month-old tg-SOD and wt mice were homogenized and measured for Gpx activity. Both genotypes demonstrated a similar level of Gpx-specific activity. C, Catalase immunoreactivity in 2-month-old tg-SOD and wt hippocampi. Homogenates from both genotypes were separated on SDS-PAGE and subjected to Western blot analysis. Similar levels of catalase were found for both genotypes. Also shown is the same blot stained with antibodies to neuron-specific enolase (NSE).

$\mathrm{H}_{2} \mathrm{O}_{2}$, by applying $10 \mu \mathrm{M} \mathrm{H}$, a broad-spectrum serine/threonine protein kinase inhibitor (Norris et al., 1998). In the presence of $\mathrm{H}_{2} \mathrm{O}_{2}$, EPSP slopes were $1.43 \pm 0.07(n=6)$ of baseline $30 \mathrm{~min}$ after TBS (Fig. $2 \mathrm{~A}$ ), indicating that the action of $\mathrm{H}_{2} \mathrm{O}_{2}$ to enhance LTP is not mediated by the activation of kinases.

\section{Antioxidant activity is not altered in tg-SOD mice}

SOD converts superoxide radicals to $\mathrm{H}_{2} \mathrm{O}_{2}$. A chronic sixfoldenhanced activity of SOD can be expected to cause a parallel compensatory change in the activity of cellular antioxidants that are responsible for the clearance of $\mathrm{H}_{2} \mathrm{O}_{2}$. Gpx reduces $\mathrm{H}_{2} \mathrm{O}_{2}$ using glutathione and is considered to be the main $\mathrm{H}_{2} \mathrm{O}_{2}$ converting enzyme in the brain. Therefore, we measured Gpx activity in homogenized hippocampi of wt and tg-SOD mice and found that they did not differ significantly (Fig. 3B); Gpx activity was $0.053 \pm 0.01$ in the wt hippocampus and $0.051 \pm 0.009 \mathrm{mM}$ $\mathrm{NADPH}$ per minute per milligram protein in the tg-SOD $(n=3)$. Another major $\mathrm{H}_{2} \mathrm{O}_{2}$-converting enzyme prevalent in peripheral systems but found also in the brain is catalase (Zimatkin and Lindros 1996). We measured catalase immunoreactivity on Western blots of hippocampus extracts (Fig. 3C). The catalase protein level was also not significantly different between tg-SOD and wt mice. These experiments indicate that neither the chronic nor the acute effects of $\mathrm{H}_{2} \mathrm{O}_{2}$ are mediated by a change in the enzymes responsible for the clearance of $\mathrm{H}_{2} \mathrm{O}_{2}$.

Our current observation that $\mathrm{H}_{2} \mathrm{O}_{2}$ enhances LTP in tg-SOD
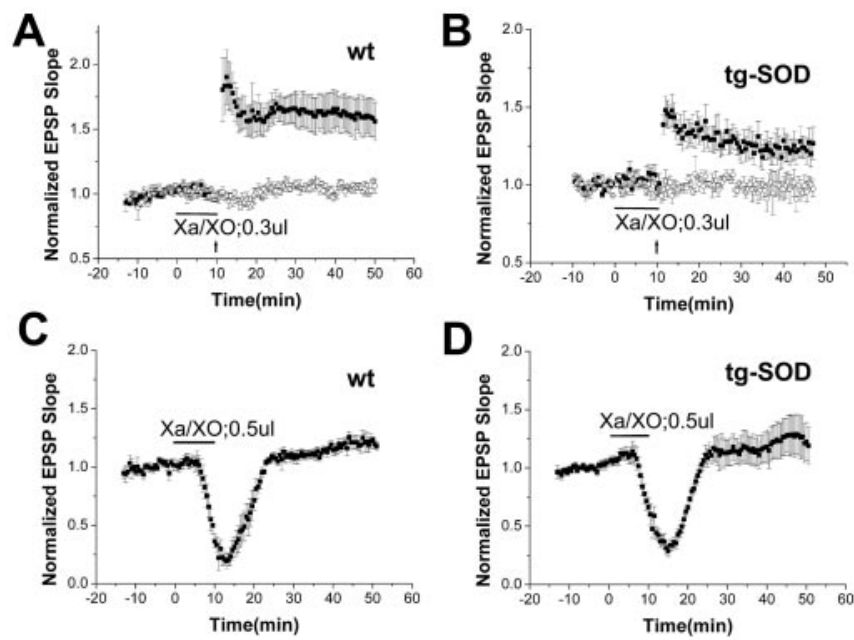

Figure 4. Mouse hippocampal slice reaction to Xa/XO. A, Wt slices (2 months old) were perfused with $0.3 \mathrm{mg} / \mathrm{ml} \mathrm{Xa}$ and $0.3 \mu \mathrm{l} / \mathrm{ml} \mathrm{XO}$ (bar). TBS was applied to one pathway (arrow, squares), and a second pathway was not tetanized. $B, A$ similar experiment, with 2-month-old $\mathrm{tg}$-SOD slices. C, D, Wt and tg-SOD slices, respectively, were perfused with $0.3 \mathrm{mg} / \mathrm{ml}$ Xa and 0.5 $\mu \mathrm{l} / \mathrm{ml} \mathrm{X0}$ (bar), resulting in a transient decline in EPSPs, followed by a slow, small but significant increase in response above baseline in both cases.

slices is seemingly contradictory to our previous findings (Gahtan et al., 1998) that BPN, a lipophilic spin-trapping antioxidant, was also effective in restoring LTP in tg-SOD slices. We were able to replicate the action of BPN in the present study (Fig. $3 A$ ) on both induction and maintenance of LTP. In the presence of BPN, EPSPs were $1.53 \pm 0.03$ of baseline 30 min after TBS $(n=$ 9), similar to wt and tg-SOD in the presence of $50 \mu \mathrm{M} \mathrm{H}_{2} \mathrm{O}_{2}$. Interestingly, BPN also affected the prepotentiated pathway, resulting in EPSPs that were $1.36 \pm 0.07$ of baseline 40 min after TBS (10 min after BPN washout), indicating that the effect of BPN on the maintenance phase of tg-SOD LTP may not be specific, and probably acts through a different molecular pathway from that activated by $\mathrm{H}_{2} \mathrm{O}_{2}$.

Together, these results indicate that the steady redox state in the hippocampus of $\mathrm{tg}$-SOD mice is not sufficient to explain both the lack of LTP and its restoration by $\mathrm{H}_{2} \mathrm{O}_{2}$.

\section{Xanthine/xanthine oxidase system does not mimic the effect of $\mathrm{H}_{2} \mathrm{O}_{2}$}

The overall redox state of a cell is the net result of the relative concentrations of myriad charged ions (Schafer and Buettner, 2001). It has been suggested that the production of superoxides rather than $\mathrm{H}_{2} \mathrm{O}_{2}$ contributes to the plastic properties of neurons (Klann, 1998). We added to the perfusion medium xanthine in the presence of xanthine oxidase (Xa/XO), a system that generates superoxide ions to affect the redox state using oxidants other than $\mathrm{H}_{2} \mathrm{O}_{2}$. In a recent study, Knapp and Klann (2002) demonstrated that in rat hippocampal slices, $\mathrm{Xa} / \mathrm{XO}$ caused a transient decrease in EPSP slopes, followed by a long-lasting increase akin to that produced by a tetanic stimulation. This LTP was mediated by the activation of protein kinase $\mathrm{C}$ in a dose-dependent manner. We used varying concentrations of $\mathrm{XO}$ with constant concentrations of xanthine while monitoring the effect on both tetanized and nontetanized pathways. Concentrations of $\mathrm{Xa} / \mathrm{XO}$ that produced LTP in rats $[2 \mu \mathrm{g} / \mathrm{ml}$ of $1 \mathrm{U} / \mathrm{mg}(\sim 2 \mathrm{mU})$, as in Knapp and Klann (2002)] had no effect on mice hippocampal slices (data not shown). Moreover, even higher concentrations of $\mathrm{Xa} / \mathrm{XO}[0.3 \mu \mathrm{l} / \mathrm{ml} \mathrm{XO}(\sim 10 \mathrm{mU})]$ (Fig. $4 A, B)$ had no effect on 

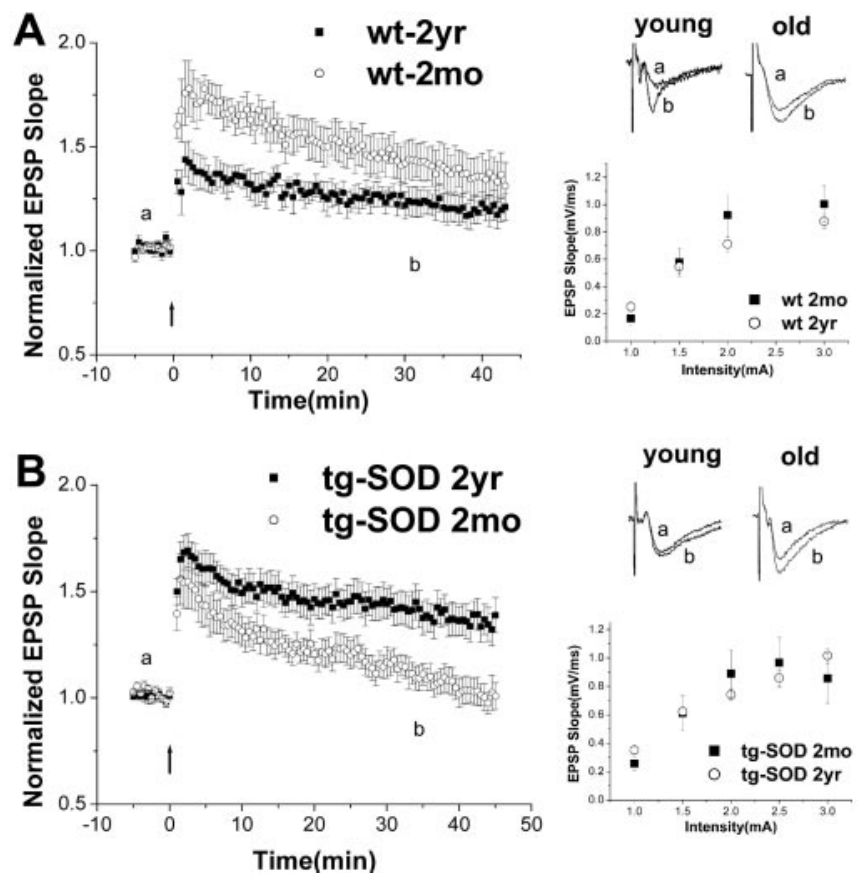

Figure 5. Slices from aged mice exhibit altered LTP.A, TBS was applied to hippocampal slices from wt mice, 2 years old (squares) and 2 months old (circles); the aged mice exhibited impaired short- and long-term potentiation. On the right is the input/output relationship for both age groups; at the top right are representative traces of the data summarized on the left. $B$, Results of the young $\mathrm{tg}$-SOD slices are same as in Figure $1 B$. Aged tg-SOD slices produced larger potentiation than their young counterparts.

baseline conditions or TBS-induced LTP. Furthermore, in the presence of $\mathrm{Xa} / \mathrm{XO}$, EPSPs of wt mice at $30 \mathrm{~min}$ after TBS were $1.63 \pm 0.14(n=6)$ of baseline, whereas EPSPs of tg-SOD mice were $1.23 \pm 0.09$ of baseline $(n=5)$, similar to nontreated slices (as in Fig. 1). An increase to $0.4 \mu \mathrm{l} / \mathrm{ml} \mathrm{XO}$ did not produce significantly different results in two slices tested (data not shown); however, an additional increase in XO concentration to $0.5 \mu \mathrm{l} / \mathrm{ml}$ $\mathrm{XO}$ resulted in transient depression of EPSPs followed by a slowonset increase in EPSPs to a level of $1.21 \pm 0.05$ for the wt mice 45 min after $\mathrm{Xa} / \mathrm{XO}$ application (Fig. $4 C$ ) and $1.27 \pm 0.14$ for tgSOD mice (Fig. $4 D)$, significantly $(p<0.01)$ higher than the baseline responses. We did not find a large increase in EPSPs similar to the level produced by TBS, as had been shown previously (Knapp and Klann, 2002), which may reflect a difference between rat and mouse slices. Furthermore, as stated, we could not mimic the effect of $\mathrm{H}_{2} \mathrm{O}_{2}$ with $\mathrm{Xa} / \mathrm{XO}$.

These results indicate that the rescue of LTP in tg-SOD mice by $\mathrm{H}_{2} \mathrm{O}_{2}$ is not the result of an overall increase in superoxides in the cells but rather represents an $\mathrm{H}_{2} \mathrm{O}_{2}$-specific mechanism.

\section{Aged tg-SOD mice express larger LTP than aged wt mice}

Hippocampal slices taken from aged rodents are impaired in their ability to express LTP (Foster, 1999). Aged individuals are also impaired in the cellular regulation of oxidative processes caused by impaired control over mitochondrial leakage, leading to a rise in ambient $\mathrm{H}_{2} \mathrm{O}_{2}$ (Beckman and Ames, 1998). Together, these findings indicate that an elevation of $\mathrm{H}_{2} \mathrm{O}_{2}$ in aged wt mice, similar to the level achieved in tg-SOD mice, may underlie their reduced ability to express LTP. We measured the ability to express LTP in slices taken from 2-year-old wt and tg-SOD mice (Fig. 5). Slices from 2-year-old mice exhibited similar input/output relationships in both wt and tg-SOD. However, EPSP slopes
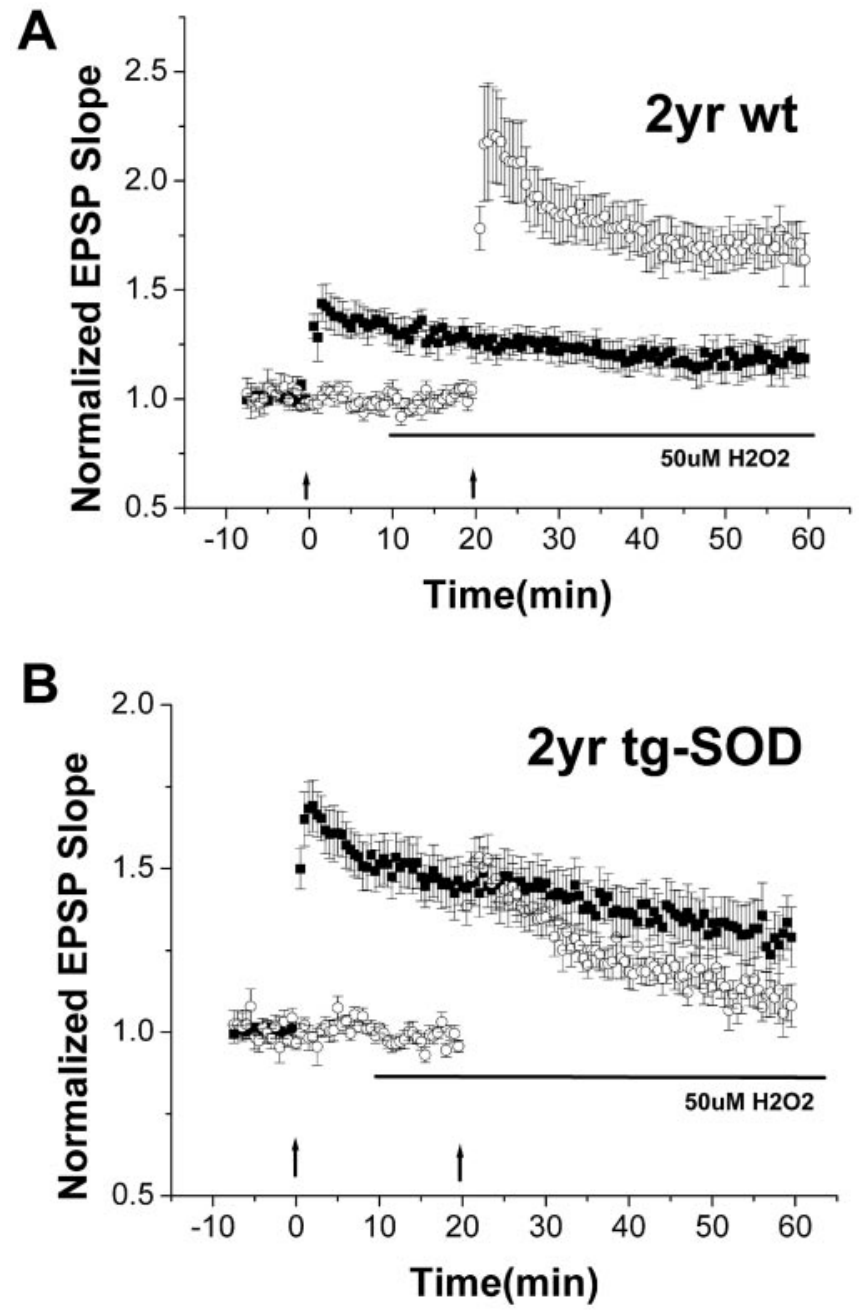

Figure 6. $\mathrm{H}_{2} \mathrm{O}_{2}$ reverses LTP phenotype in aged mice. $A$, TBS (arrows), applied to aged wt mice before (squares) and after (circles) perfusion with $50 \mu \mathrm{M} \mathrm{H}_{2} \mathrm{O}_{2}$ resulted in a large enhancement of both short- and long-term potentiation. $B$, In tg-SOD slices, under the same conditions, $50 \mu \mathrm{M} \mathrm{H}_{2} \mathrm{O}_{2}$ markedly attenuated LTP.

were only $1.21 \pm 0.06$ of baseline $30 \mathrm{~min}$ after TBS in 2-year-old wt mice $(n=8)$ (Fig. $5 A)$, which was significantly lower than the change obtained in 2-month-old mice $(1.44 \pm 0.09 ; F=10.7 ; p<$ $0.05)$. Strikingly, an opposite effect of aging was seen in the tgSOD mice (Fig. $5 B$ ), in which EPSPs of the 2-year-old tg-SOD mice were $1.45 \pm 0.07$ of baseline $30 \mathrm{~min}$ after TBS $(n=13)$, significantly $(F=11.3 ; p<0.05)$ higher than that of 2 -month-old $\operatorname{tg}$-SOD mice $(1.17 \pm 0.04)$.

\section{$\mathrm{H}_{2} \mathrm{O}_{2}$ restores LTP in aged wt and inhibits LTP in aged tg-SOD mice}

Because aged wt mice are impaired in LTP, as are young tg-SOD mice, we examined whether $\mathrm{H}_{2} \mathrm{O}_{2}$ can also enhance LTP in aged wt mice. Indeed, the EPSPs of 2 -year-old wt mice increased to $1.66 \pm 0.08$ of baseline levels $30 \mathrm{~min}$ after TBS in the presence of $50 \mu \mathrm{M} \mathrm{H}_{2} \mathrm{O}_{2},(n=9)$ (Fig. $\left.6 A\right)$, significantly $(F=29.44 ; p<0.05)$ higher than the pathway stimulated without $\mathrm{H}_{2} \mathrm{O}_{2}$. In contrast, tg-SOD slices showed the reverse phenomenon, whereby exposure to $50 \mu \mathrm{M} \mathrm{H} \mathrm{H}_{2} \mathrm{O}_{2}$ resulted in a reduced enhancement of the EPSP slopes that were now only $1.17 \pm 0.06$ of baseline $30 \mathrm{~min}$ after TBS $(n=11)$ (Fig. $6 B)$, significantly $(F=17.2 ; p<0.05)$ lower than the pathway potentiated without $\mathrm{H}_{2} \mathrm{O}_{2}$. These data 

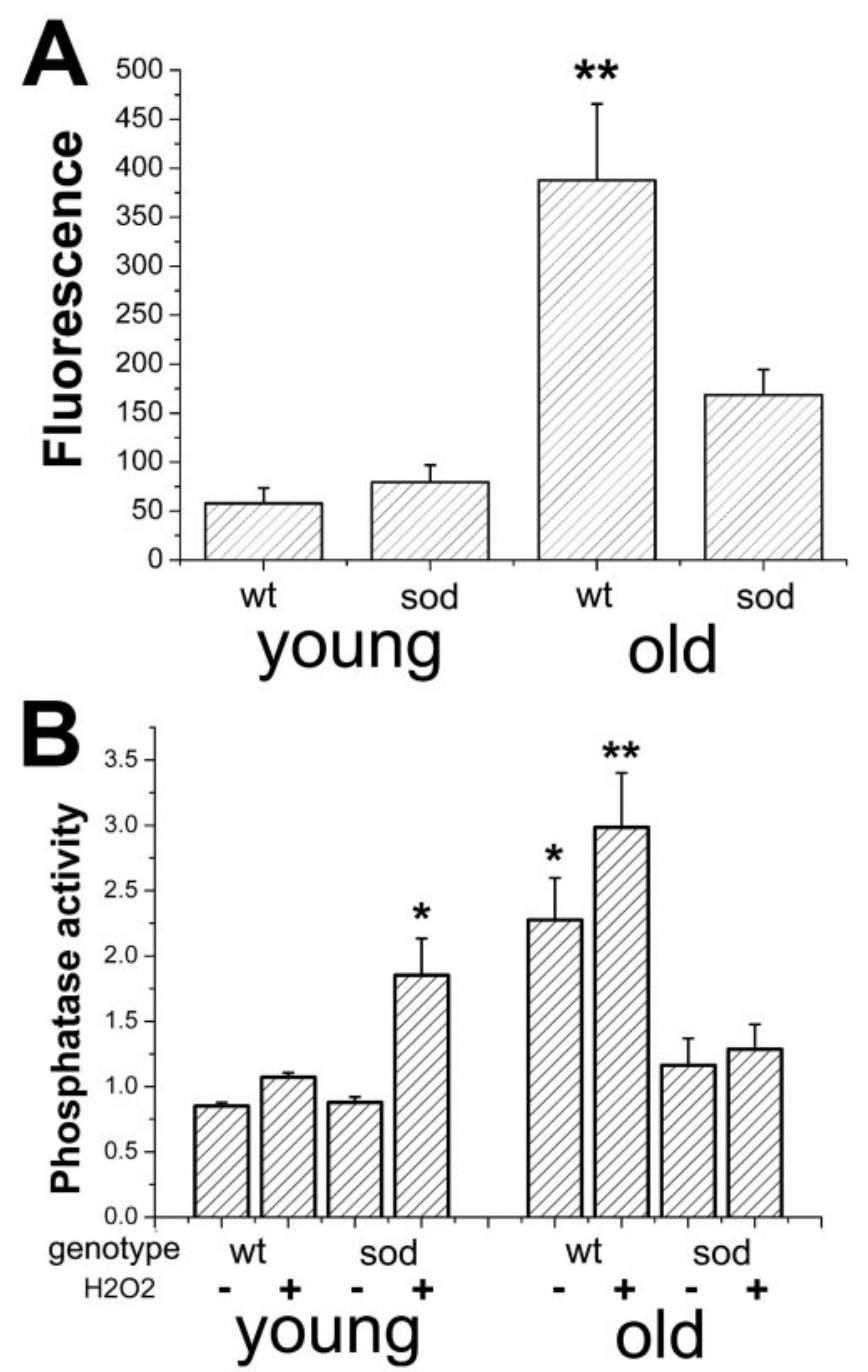

Figure 7. Age and genotype affect endogenous $\mathrm{H}_{2} \mathrm{O}_{2}$ level and phosphatase activity. $A$, Hippocampal slices from young and old wt and tg-SOD mice were placed in HEPES-buffered medium in an imaging chamber. $\mathrm{An}_{2} \mathrm{O}_{2}$-sensitive fluorescent dye (2,7-DCF) was added to the medium, and fluorescence was measured at $488 \mathrm{~nm}$. Young tg-SOD mice exhibited slightly higher fluorescence than wt mice, whereas old wt mice exhibited significantly higher fluorescence than old tg-SOD mice. $B$, Phosphatase activity was measured for old and young hippocampal slices with or without $50 \mu \mathrm{M} \mathrm{H}_{2} \mathrm{O}_{2}$ (see Results for details).

highlight a similarity between aged wt mice and young tg-SOD mice to indicate that apparently high ambient $\mathrm{H}_{2} \mathrm{O}_{2}$ in both cases may cause deterioration of the ability to express LTP. Interestingly, in both cases the addition of $\mathrm{H}_{2} \mathrm{O}_{2}$ restored this ability. Still, aged tg-SOD expressed higher LTP than wt controls or young tg-SOD mice; this will be analyzed below.

\section{Aged wt mice and young tg-SOD mice produce $\mathrm{H}_{2} \mathrm{O}_{2}$ and} express altered phosphatase activity

Reliable and accurate measurements of rapid changes in concentrations of ROS in live brain tissue are currently unavailable. As a tentative estimate of $\mathrm{H}_{2} \mathrm{O}_{2}$ concentrations, we used a variation of a method described by Cathcart et al. (1983), applying an $\mathrm{H}_{2} \mathrm{O}_{2}$ sensitive fluorescent dye (2,7-DCF) to hippocampal slices from young and old wt and tg-SOD mice and measuring the fluorescence at $488 \mathrm{~nm}$ (Fig. 7A). The results indicate that young tg-SOD mice had a slightly higher level of $\mathrm{H}_{2} \mathrm{O}_{2}$ [79.6 \pm 17 optical density (OD) units] than young wt mice ( $58 \pm 15$ OD units). Aged tg-
SOD mice showed a markedly lower level of $\mathrm{H}_{2} \mathrm{O}_{2}(168 \pm 26)$ than their corresponding old wt slices $(388 \pm 77)$. Altogether, aged mice had significantly $(F=21.13 ; p<0.05)$ higher levels of $\mathrm{H}_{2} \mathrm{O}_{2}$ than young mice.

Blockade of calcineurin can reverse the effects of $\mathrm{H}_{2} \mathrm{O}_{2}$ (Kamsler and Segal, 2003) (Fig. 2). Calcineurin dephosphorylates inhibitor 1 (I-1), which in turn releases a serine/threonine phosphatase (PP1), which can dephosphorylate protein kinase A substrates (Mulkey et al., 1994). Therefore, we measured the total serine/threonine phosphatase activity in young and old wt and tg-SOD hippocampal slices in controls and after exposure to 50 $\mu \mathrm{M} \mathrm{H}_{2} \mathrm{O}_{2}$ (Fig. $7 B$ ). Extracts from young tg-SOD mice released $0.88 \pm 0.04 \mathrm{nmol} \mathrm{PO}_{4}$ in $15 \mathrm{~min}$, which was similar to that released by wt mice $(0.85 \pm 0.02)$. However, they did show a significant increase in response to $\mathrm{H}_{2} \mathrm{O}_{2}$ to a level of $1.85 \pm 0.28$ $(p<0.01 ; n=5)$, whereas wt extracts showed only a slight increase, to a level of $1.07 \pm 0.03$. Slices from aged wt mice exhibited a high phosphatase activity, which was further enhanced by $\mathrm{H}_{2} \mathrm{O}_{2}(2.28 \pm 0.32$ and $2.99 \pm 0.4$, respectively $)$. This activity was significantly higher than either young wt $(p<0.01)$ or aged $\operatorname{tg}$-SOD $(1.164 \pm 0.2,1.29 \pm 0.2$, respectively; $p<0.05)$ mice. Thus, serine/threonine phosphatase activity is altered in young tg-SOD mice by $\mathrm{H}_{2} \mathrm{O}_{2}$ under the same conditions that promote LTP. In the aged mice, wt slices are deficient in LTP, and under higher ROS conditions they also express a higher phosphatase activity. Therefore, we can correlate high ROS background with altered phosphatase activity and low LTP that is rescued by the exogenous addition of $\mathrm{H}_{2} \mathrm{O}_{2}$.

\section{FK506 inhibits LTP in old wt mice treated with $\mathrm{H}_{2} \mathrm{O}_{2}$ and in old tg-SOD mice}

The addition of $50 \mu \mathrm{M} \mathrm{H}_{2} \mathrm{O}_{2}$ restored LTP in slices taken from old wt mice in a manner similar to that shown for young tg-SOD mice (Fig. 6A). This treatment also enhanced serine/threonine phosphatase activity in these slices (Fig. 7B). Therefore, we examined whether this enhanced LTP could be blocked by FK506 in a manner similar to the effect seen in young tg-SOD slices treated with $\mathrm{H}_{2} \mathrm{O}_{2}$ (Fig. 2A). Indeed we found a significant $(p<0.05$; $n=10)$ reduction in LTP after exposure to the drug; the EPSP slope of $\mathrm{H}_{2} \mathrm{O}_{2}$-treated slices was $1.66 \pm 0.08$ of baseline $30 \mathrm{~min}$ after TBS, whereas the addition of FK506 resulted in an EPSP that was $1.35 \pm 0.05$ of baseline (Fig. $8 A$ ). Slices from old tg-SOD mice exhibited LTP (Fig. $5 B$ ) and were under higher oxidative status than young tg-SOD slices (Fig. 7A). Therefore, we sought to examine whether inhibiting calcineurin in such slices would have an effect similar to that produced in young tg-SOD slices exposed to $\mathrm{H}_{2} \mathrm{O}_{2}$. Indeed, although slices from old tg-SOD mice exhibited LTP at a level of $1.44 \pm 0.08$ of baseline $30 \mathrm{~min}$ after TBS (and $1.55 \pm 0.07$ at $10 \mathrm{~min}$ after TBS), treating similar slices with FK506 resulted in a significant $(p<0.05 ; n=8)$ reduction in LTP to an EPSP slope that was $1.22 \pm 0.08$ of baseline some $30 \mathrm{~min}$ after TBS (and $1.34 \pm 0.0810 \mathrm{~min}$ after TBS). Thus, at both time points, the effect of FK506 was significant statistically (Fig. 8 B).

\section{Discussion}

The present series of studies has analyzed two paradoxical observations on the action of $\mathrm{H}_{2} \mathrm{O}_{2}$ in neural plasticity: As seen previously (Gahtan et al., 1998), slices of Tg-SOD mice, which apparently overproduce $\mathrm{H}_{2} \mathrm{O}_{2}$, expressed lower LTP in response to the tetanic stimulation of afferent pathways than slices from normal mice. Surprisingly, this impairment could be overcome by the addition of $\mathrm{H}_{2} \mathrm{O}_{2}$ at a concentration that impaired LTP in the control wt mice. Conversely, aged tg-SOD mice exhibited larger 

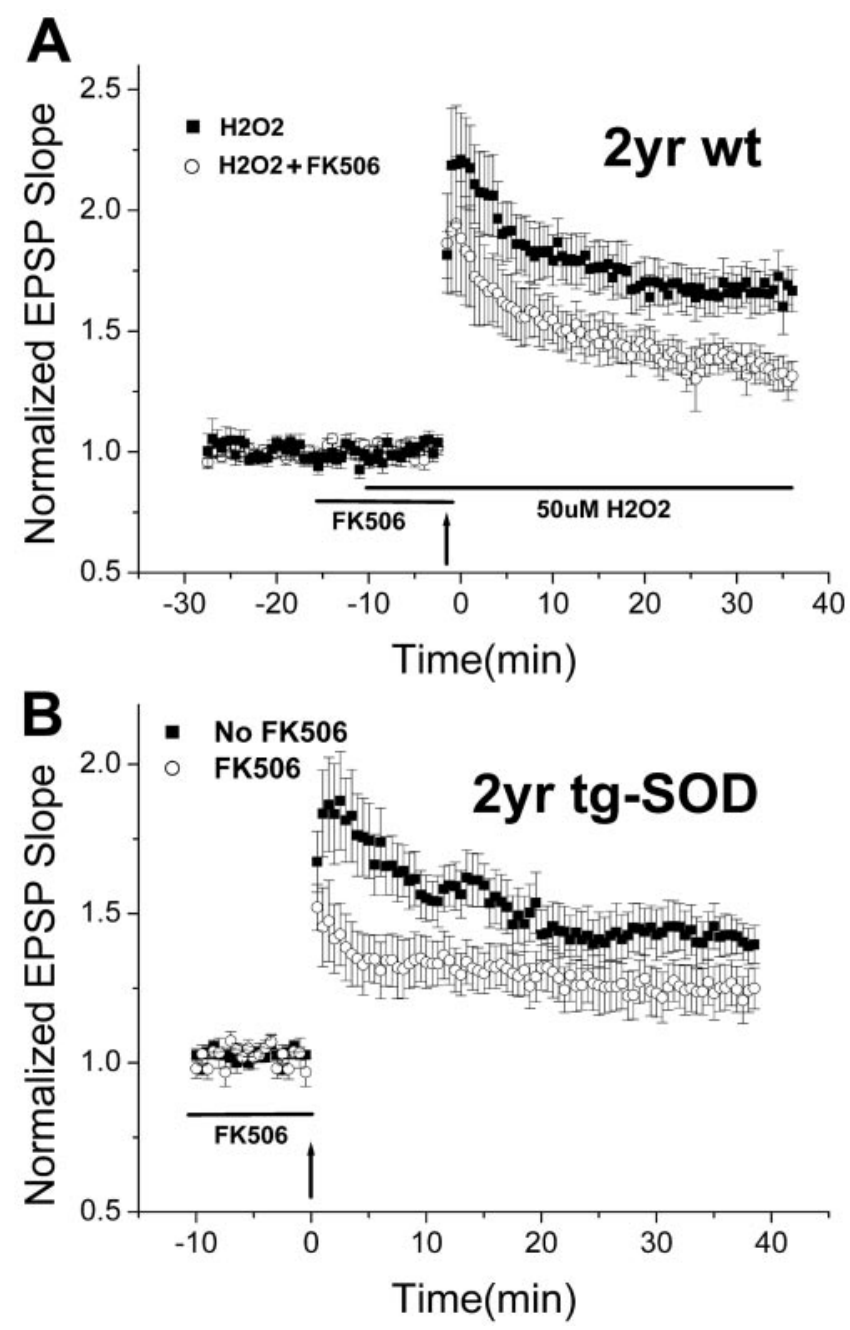

Figure 8. FK506 inhibits LTP in old wt mice treated with $\mathrm{H}_{2} \mathrm{O}_{2}$ and in old tg-SOD mice. $A$, Slices from 2-year-old wt mice perfused with $50 \mu \mathrm{M} \mathrm{H}_{2} \mathrm{O}_{2}$ alone (squares) expressed LTP, whereas slices perfused with $\mathrm{H}_{2} \mathrm{O}_{2}$ and $20 \mu \mathrm{m}$ FK506 (circles) exhibited significantly lower LTP. $B$, Slices from 2-year-old tg-SOD mice exhibited LTP (squares), whereas the addition of $20 \mu \mathrm{m}$ FK506 to the perfusion medium resulted in significantly lower LTP (circles).

LTP than that produced by wt slices. The effects of $\mathrm{H}_{2} \mathrm{O}_{2}$ were reversed in the aged mice; LTP in tg-SOD slices was impaired by the addition of $\mathrm{H}_{2} \mathrm{O}_{2}$, whereas LTP of wt slices was enhanced by $\mathrm{H}_{2} \mathrm{O}_{2}$.

In an attempt to resolve these paradoxical observations, we found that the young tg-SOD mice and the aged wt mice exhibited elevated levels of endogenous $\mathrm{H}_{2} \mathrm{O}_{2}$ and had different protein phosphatase activity with or without exogenous $\mathrm{H}_{2} \mathrm{O}_{2}$. Although protein phosphatases are considered to be facilitators of longterm depression rather than potentiation (Bear and Abraham, 1996), blocking the protein phosphatase calcineurin was effective in eliminating the $\mathrm{H}_{2} \mathrm{O}_{2}$-dependent potentiation in young tgSOD mice.

The striking reciprocity between aged wt and young tg-SOD mice, especially with regard to the beneficial effect of $\mathrm{H}_{2} \mathrm{O}_{2}$ on LTP, may shed new light on the role of ROS in aging of the nervous system. A parallel deficiency in LTP was found in rat slices exposed to superoxide scavenging compounds (Klann, 1998) and transgenic mice overexpressing an extracellular form of SOD (Thiels et al., 2000). These findings led to a novel hypothesis, suggesting that a transient increase in superoxide radicals

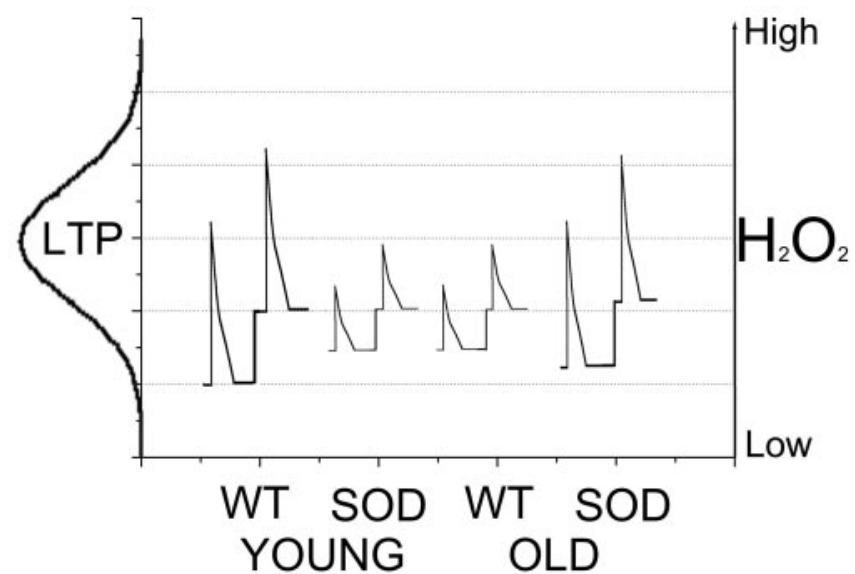

Figure 9. Schematic representation of the effect of ambient $\mathrm{H}_{2} \mathrm{O}_{2}$ levels on LTP. As described in Discussion, there is a threshold level of $\mathrm{H}_{2} \mathrm{O}_{2}$ necessary for optimal LTP. Deviating from that level in either direction will reduce the expression of LTP. Young wt mice maintain an ambient level of $\mathrm{H}_{2} \mathrm{O}_{2}$ that allows a transient, stimulus-induced flux of $\mathrm{H}_{2} \mathrm{O}_{2}$ to promote LTP. The exogenous addition of $\mathrm{H}_{2} \mathrm{O}_{2}$ drives the ambient level higher, inhibiting LTP. Tg-SOD mice maintain a high ambient level of $\mathrm{H}_{2} \mathrm{O}_{2}$ that induces a high level of anti- $\mathrm{H}_{2} \mathrm{O}_{2}$ cellular mechanisms, which in turn desensitize the cells to a transient $\mathrm{H}_{2} \mathrm{O}_{2}$ flux. Adding exogenous $\mathrm{H}_{2} \mathrm{O}_{2}$ increases the $\mathrm{H}_{2} \mathrm{O}_{2}$ level to a suprathreshold concentration. Old wt mice are under high ambient $\mathrm{H}_{2} \mathrm{O}_{2}$ levels because of mitochondrial leakage, and react in a similar manner. Old tg-SOD mice have an ambient $\mathrm{H}_{2} \mathrm{O}_{2}$ level that is the result of both transgene and age, resulting in a level of $\mathrm{H}_{2} \mathrm{O}_{2}$ on stimulation that remains high long enough to achieve the LTP threshold.

was necessary for LTP. Moreover, Knapp and Klann (2002) have demonstrated that production of superoxides alone was sufficient for the induction of LTP, in the absence of a tetanic stimulation, in a PKC-dependent manner.

The management of ROS in living cells has been extensively studied (for review, see Halliwell, 1992). Superoxides that are produced by mitochondria but also by activation of NMDA receptors (Lafon-Cazal et al., 1993) are reduced by SOD to $\mathrm{H}_{2} \mathrm{O}_{2}$, which can be further reduced to $\mathrm{H}_{2} \mathrm{O}$ and $\mathrm{O}_{2}$ by catalase or glutathione peroxidase. The activity of these enzymes can be modified by the relative concentrations of the reactants. Furthermore, high ambient levels of $\mathrm{H}_{2} \mathrm{O}_{2}$ react with iron ions to produce highly toxic hydroxyl radicals (Halliwell, 1992). The cellular mechanisms that deal with these ROS are activated in response to the overall cellular redox level, which is the net result of all of the ambient ROS (Schafer and Buettner, 2001). Thus, an increase in $\mathrm{H}_{2} \mathrm{O}_{2}$ may alter the equilibrium state of ROS and cause an increase in the effectiveness of scavenging mechanisms.

We propose that $\mathrm{H}_{2} \mathrm{O}_{2}$ regulates synaptic plasticity in a complex manner that depends on an interaction between the preexisting redox state and a transient, tetanic stimulation-induced rise in $\mathrm{H}_{2} \mathrm{O}_{2}$. With a low ambient concentration of $\mathrm{H}_{2} \mathrm{O}_{2}$ that is present in young wt mice, the tetanic stimulation will produce a large transient rise in $\mathrm{H}_{2} \mathrm{O}_{2}$, which will facilitate the establishment of LTP. An additional increase in ambient $\mathrm{H}_{2} \mathrm{O}_{2}$, which is added by perfusion, will cause $\mathrm{H}_{2} \mathrm{O}_{2}$ to rise to a high level that is detrimental to LTP (Fig. 9). Young tg-SOD mice that overproduce ambient $\mathrm{H}_{2} \mathrm{O}_{2}$ contain an intracellular redox environment that is different from that of wt counterparts. Their intracellular milieu of proteins functions at a higher level of $\mathrm{H}_{2} \mathrm{O}_{2}$ and is therefore desensitized to the small rise in $\mathrm{H}_{2} \mathrm{O}_{2}$ that follows the tetanic stimulation, which cannot pass the threshold necessary for producing LTP. In these slices, another addition of $\mathrm{H}_{2} \mathrm{O}_{2}$ by perfusion will allow the $\mathrm{H}_{2} \mathrm{O}_{2}$ level after tetanic stimulation to pass this threshold. Aged wt mice that produce more $\mathrm{H}_{2} \mathrm{O}_{2}$ be- 
cause of mitochondrial leakage (Beckman and Ames, 1998) are desensitized and do not allow a large transient change in $\mathrm{H}_{2} \mathrm{O}_{2}$, but the addition of exogenous $\mathrm{H}_{2} \mathrm{O}_{2}$ may cause an increase in total $\mathrm{H}_{2} \mathrm{O}_{2}$ to a level that is beneficial for LTP. Finally, aged tg-SOD mice have a genetic desensitization caused by the overproduction of $\mathrm{H}_{2} \mathrm{O}_{2}$, which is accompanied by age-dependent mitochondrial leakage that may be evident from the mitochondrial vacuolization seen in these mice (Jaarsma et al., 2000), producing a state that is again sensitive to acute changes in $\mathrm{H}_{2} \mathrm{O}_{2}$ levels (Fig. 9).

Our hypothesis predicts that the tetanic stimulation causes a surge in $\mathrm{H}_{2} \mathrm{O}_{2}$, and that the size of this surge is dependent on ambient levels of $\mathrm{H}_{2} \mathrm{O}_{2}$. Because at present it is impossible to measure micromolar fluctuations of $\mathrm{H}_{2} \mathrm{O}_{2}$ in living tissue over a millisecond time scale, the direct test of our predictions will await the development of such methods.

It must be kept in mind that the slicing procedure itself may release ROS from the hippocampal slices. The antioxidants ascorbic acid and glutathione leak from hippocampal slices placed in ACSF (Rice, 1999), causing changes in the cellular redox state. However, not all of the changes in LTP can be associated with the preparation of slices, because aged animals show impaired memory, as do tg-SOD mice. Interestingly, aged tg-SOD mice perform better on a radial arm maze task than aged wt mice (Levin et al., 2002), showing an in vivo interaction between the effects of age and SOD, in congruence with our results.

$\mathrm{H}_{2} \mathrm{O}_{2}$ can affect protein phosphatase activity (Huang et al., 2001, Kamsler and Segal, 2003), possibly through the release of calcium from internal stores (Herson et al., 1999). Moreover, calcineurin has been shown to be activated by $\mathrm{H}_{2} \mathrm{O}_{2}$. Nuclear factor of activated T cells (NFAT) is a transcription factor that is activated by calcineurin. NFAT activity can be induced by asbestos (Li et al., 2002) or vanadium (Huang et al., 2001) in a manner that is dependent on $\mathrm{H}_{2} \mathrm{O}_{2}$ production. It can be enhanced by the $\mathrm{H}_{2} \mathrm{O}_{2}$-producing enzyme SOD and can be blocked by the calcineurin inhibitor cyclosporin A. Inactivation of calcineurin by $\mathrm{H}_{2} \mathrm{O}_{2}$ has been shown previously (Bogumil et al., 2000); however, this study used $1 \mathrm{mM} \mathrm{H}_{2} \mathrm{O}_{2}$ for time dependence of the reaction, showing a $75 \%$ activity decrease after $30 \mathrm{~min}$. These results cannot rule out the activation of calcineurin by micromolar concentrations of $\mathrm{H}_{2} \mathrm{O}_{2}$.

The change in phosphatase activity may be a way by which the redox state of the cell is translated to the working state of various proteins, including ion channels. Changes in the permeability of voltage-dependent calcium channels can cause changes in the opening duration of calcium-dependent potassium channels, which can cause an increase in afterhyperpolarization such as that evident in aged individuals (Thibault et al., 2001), providing a possible link between the cellular redox level and behavior.

In summary, the ambient redox state of neuronal systems can affect their reaction to plasticity-producing stimuli. Moreover, this state can be adjusted either in a chronic manner by age or a transgene or in an acute manner with drastically different effects. ROS as a whole, and particularly $\mathrm{H}_{2} \mathrm{O}_{2}$, should not be regarded merely as agents of oxidative stress but as important and specific signaling molecules in a cascade of events leading to synaptic plasticity.

\section{References}

Anderson WW, Collingridge GL (2001) The LTP Program: a data acquisition program for on-line analysis of long-term potentiation and other synaptic events. J Neurosci Methods 108:71-83.

Bear MF, Abraham WC (1996) Long-term depression in hippocampus. Annu Rev Neurosci 19:437-462.
Beckman KB, Ames BN (1998) The free radical theory of aging matures. Physiol Rev 78:547-581.

Bogumil R, Namgaladze D, Schaarschmidt D, Schmachtel T, Hellstern S, Mutzel R, Ullrich V (2000) Inactivation of calcineurin by hydrogen peroxide and phenylarsine oxide: evidence for a dithiol-disulfide equilibrium and implications for redox regulation. Eur J Biochem 267:1407-1415.

Cathcart R, Schwiers E, Ames BN (1983) Detection of picomole levels of hydroperoxides using a fluorescent dichlorofluorescein assay. Anal Biochem 134:111-116.

Davson H (1964) A textbook of general physiology. London: Churchill.

Epstein CJ, Avraham KB, Lovett M, Smith S, Elroy-Stein O, Rotman G, Bry C, Groner Y (1987) Transgenic mice with increased Cu/Zn-superoxide dismutase activity: animal model of dosage effects in Down syndrome. Proc Natl Acad Sci USA 84:8044-8048.

Flohe L, Gunzler WA (1984) Assays of glutathione peroxidase. Methods Enzymol 105:114-1121.

Foster TC (1999) Involvement of hippocampal synaptic plasticity in agerelated memory decline. Brain Res Brain Res Rev 30:236-249.

Foster TC, Sharrow KM, Masse JR, Norris CM, Kumar A (2001) Calcineurin links $\mathrm{Ca}^{2+}$ dysregulation with brain aging. J Neurosci 21:4066-4073.

Gahtan E, Auerbach JM, Groner Y, Segal M (1998) Reversible impairment of long-term potentiation in transgenic $\mathrm{Cu} / \mathrm{Zn}$-SOD mice. Eur J Neurosci 10:538-544.

Halliwell B (1992) Reactive oxygen species and the central nervous system. J Neurochem 59:1609-1623.

Herson PS, Lee K, Pinnock RD, Hughes J, Ashford ML (1999) Hydrogen peroxide induces intracellular calcium overload by activation of a nonselective cation channel in an insulin-secreting cell line. J Biol Chem 274:833-841.

Huang C, Ding M, Li J, Leonard SS, Rojanasakul Y, Castranova V, Vallyathan V, Ju G, Shi X (2001) Vanadium-induced nuclear factor of activated T cells activation through hydrogen peroxide. J Biol Chem 276:22397-22403.

Jaarsma D, Haasdijk ED, Grashorn JA, Hawkins R, van Duijn W, Verspaget HW, London J, Holstege JC (2000) Human Cu/Zn superoxide dismutase (SOD1) overexpression in mice causes mitochondrial vacuolization, axonal degeneration, and premature motoneuron death and accelerates motoneuron disease in mice expressing a familial amyotrophic lateral sclerosis mutant SOD1. Neurobiol Dis 7:623-643.

Kamsler A, Segal M (2003) Hydrogen peroxide modulation of synaptic plasticity. J Neurosci 23:269-276.

Kinouchi H, Epstein CJ, Mizui T, Carlson E, Chen SF, Chan PH (1991) Attenuation of focal cerebral ischemic injury in transgenic mice overexpressing CuZn superoxide dismutase. Proc Natl Acad Sci USA $88: 11158-11162$

Klann E (1998) Cell-permeable scavengers of superoxide prevent long-term potentiation in hippocampal area CA1. J Neurophysiol 80:452-457.

Klann E, Thiels E (1999) Modulation of protein kinases and protein phosphatases by reactive oxygen species: implications for hippocampal synaptic plasticity. Prog Neuropsychopharmacol Biol Psychiatry 23:359-376.

Knapp LT, Klann E (2002) Potentiation of hippocampal synaptic transmission by superoxide requires the oxidative activation of protein kinase $\mathrm{C}$. J Neurosci 22:674-683.

Lafon-Cazal M, Pietri S, Culcasi M, Bockaert J (1993) NMDA-dependent superoxide production and neurotoxicity. Nature 364:535-537.

Levin ED, Christopher NC, Lateef S, Elamir BM, Patel M, Liang LP, Crapo JD (2002) Extracellular superoxide dismutase overexpression protects against aging-induced cognitive impairment in mice. Behav Genet 32:119-125.

Levkovitz Y, Avignone E, Groner Y, Segal M (1999) Upregulation of GABA neurotransmission suppresses hippocampal excitability and prevents longterm potentiation in transgenic superoxide dismutase-overexpressing mice. J Neurosci 19:10977-10984.

Li J, Huang B, Shi X, Castranova V, Vallyathan V, Huang C (2002) Involvement of hydrogen peroxide in asbestos-induced NFAT activation. Mol Cell Biochem 234-235:161-168.

Morgan SL, Teyler TJ (2001) Electrical stimuli patterned after the thetarhythm induce multiple forms of LTP. J Neurophysiol 86:1289-1296. 
Mulkey RM, Endo S, Shenolikar S, Malenka RC (1994) Involvement of a calcineurin/inhibitor-1 phosphatase cascade in hippocampal long-term depression. Nature 369:486-488.

Norris CM, Halpain S, Foster TC (1998) Alterations in the balance of protein kinase/phosphatase activities parallel reduced synaptic strength during aging. J Neurophysiol 80:1567-1570.

Peled-Kamar M, Lotem J, Okon E, Sachs L, Groner Y (1995) Thymic abnormalities and enhanced apoptosis of thymocytes and bone marrow cells in transgenic mice overexpressing $\mathrm{Cu} / \mathrm{Zn}$-superoxide dismutase: implications for Down syndrome. EMBO J 14:4985-4993.

Rice ME (1999) Use of ascorbate in the preparation and maintenance of brain slices. Methods 18:144-149.

Saito A, Hayashi T, Okuno S, Ferrand-Drake M, Chan PH (2003) Overexpression of copper/zinc superoxide dismutase in transgenic mice protects against neuronal cell death after transient focal ischemia by blocking activation of the Bad cell death signaling pathway. J Neurosci 23:1710-1718.
Schafer FQ, Buettner GR (2001) Redox environment of the cell as viewed through the redox state of the glutathione disulfide/glutathione couple. Free Radic Biol Med 30:1191-1212.

Thibault O, Hadley R, Landfield PW (2001) Elevated postsynaptic $\left[\mathrm{Ca}^{2+}\right]_{\mathrm{i}}$ and L-type calcium channel activity in aged hippocampal neurons: relationship to impaired synaptic plasticity. J Neurosci 21:9744-9756.

Thiels E, Urban NN, Gonzalez-Burgos GR, Kanterewicz BI, Barrionuevo G, Chu CT, Oury TD, Klann E (2000) Impairment of long-term potentiation and associative memory in mice that overexpress extracellular superoxide dismutase. J Neurosci 20:7631-7639.

Yarom R, Sapoznikov D, Havivi Y, Avraham KB, Schickler M, Groner Y (1988) Premature aging changes in neuromuscular junctions of transgenic mice with an extra human CuZnSOD gene: a model for tongue pathology in Down's syndrome. J Neurol Sci 88:41-53.

Zimatkin SM, Lindros KO (1996) Distribution of catalase in rat brain: aminergic neurons as possible targets for ethanol effects. Alcohol Alcohol $31: 167-174$. 